THE USE OF STORY FACE IN TEACHING READING

COMPREHENSION OF NARRATIVE TEXT IN SMK SWASTA DWIWARNA MEDAN

AN ARTICLE

Submitted in Partial Fulfillment of the Requirements for the Degree of SarjanaPendidikan

By:

Maisaroh Sartika Damanik

Registration Number: 2151121028

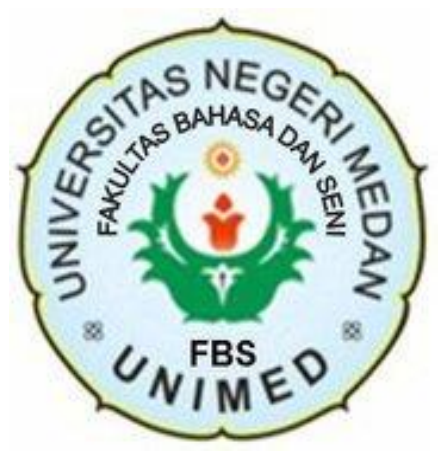

ENGLISH AND LITERATURE DEPARTMENT

FACULTY OF LANGUAGES AND ARTS STATE UNIVERSITY OF MEDAN 


\section{ARTIKEL \\ THE USE OF STORY FACE IN TEACHING READING COMPREHENSION OF NARRATIVE TEXT IN SMK SWASTA DWIWARNA MEDAN}

Disusun dan Diajukan oleh:

\section{Maisaroh Sartika Damanik} NIM. 2151121028

Telah diverifikasi dan dinyatakan memenuhi syarat untuk diunggah pada jurnal online

Medan, Agustus 2020

Menyetujui

Dosen Pembimbing I

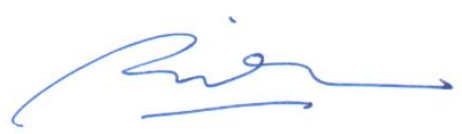

Rika, S.Pd., M.Hum. NIP. 197807172008122011
Dosen Pembimbing II

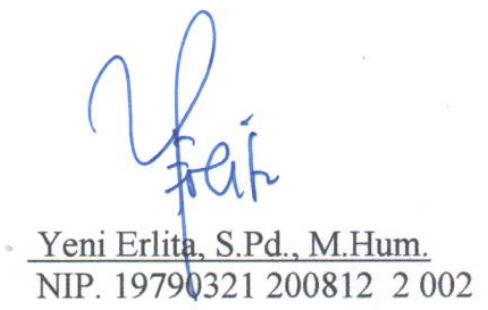

Ka. Program Studi Pendidikan Bahasa Inggris

Nora Ronita Dewi, S. Pd., S. S., M. Hum.

NIP.19800522 2008122003 


\title{
THE USE OF STORY FACE IN TEACHING READING COMPREHENSION OF NARRATIVE TEXT IN SMK SWASTA DWIWARNA MEDAN
}

\author{
*Maisaroh sartika Damanik \\ **Rika \\ **Yeni Erlita
}

\begin{abstract}
This study was aimed to find out the process of teaching reading comprehension through story face of narrative text and students' problems in the process of learning reading comprehension through story face of narrative text. The research was conducted by using descriptive qualitative. The data were analyzed by qualitative analysis technique which consists of three procedures, namely: data condentation, data display and drawing/conclusion. The data were the result of observing and interviewing of students at SMK Swasta Dwiwarna Medan. The data were analyzed based on teaching reading comprehension through story face by Randolp (2012). The findings showed that the process of teaching learning reading by using story face could help the students in learning reading but teaching reading comprehension by using story face was still less effective in grade tenth in SMK Swasta Dwiwarna Medan. The teacher had followed the procedure well based on the Randolp(2012), but the teacher did not manage the time well. There were some students' problems in learning reading comprehension of narrative text by using story face. The problems were: (a) students lack vocabulary mastery, (b) The students had problem to decode words and sentence, (c) Students had problem to get main idea of the text and to figure out the inference of the text, (d) Students had habit of slow reading, (e) Students had problem in working memory to remember the text, (f) students were being passive during learning process and they did not confidence, they felt afraid to make a mistake in learning reading.
\end{abstract}

Key words:Reading comprehension, students' problems in learning reading, Story Face, Teaching reading story face.

\footnotetext{
*Graduate Status

**Lecturer Status
} 


\section{INTRODUCTION}

Language is use for communication (Brown, 2000:5). Based on the statement, language is the most important things in communication, and it is used as a tool of communication among the people around the world. Every country has its own language to one another. For Indonesia, English is as a foreign language. . Brown (2004:185) states that reading arguably the most essential skill for success in all educational contexts. That statement is supported by Carrel (1988:1) states that reading is the most important of the four skills, particularly in foreign language.English has four skills: these skills are important part in communication. The skills are listening, speaking, reading and writing.

Reading skill is one of the skills that should be mastered by the students in almost all levels of school. Reading can be defined as perceiving a written text in order to understand its content (Richard et al, 2002:454). Reading is one of important aspects to learn language.Reading is a complex, purposeful, interactive, comprehending, and flexible activity that takes considerable time and resources to develop. Reading is very essential to get information from the text.

Aebersold and Field (1997:15) states that reading is what happens when people look at the text and assign meaning to the written symbols in that text, further, the text and reader are two physical entities necessary for the reading process to begin.

In reading activity, the reader should understand the idea delivered by the text. A text can be divided into many kinds. One of them is narrative story. Narrative story as a cultural product is important for students to motivate imagination (carter, 2005:3). The study on story as a cultural product is important to conduct because any time it improves meaning, forming, creation, and imagination of students. Students sometimes are hard to find the answer of the questions in the text. They have to comprehend main idea of the text. Especially in reading narrative text, the students had the problem to understand the content of reading text, to understand the meaning words in 
reading text and the teacher does not give interest strategy to students. Therefore, students are less exited to read the narrative text because the teacher's strategy just asks student to read a text and answer the question.

Story face is one of strategies that can be used in comprehend the text to help students. According to Staal (2000: 79) the story face strategy is easier to understand. It is supported by Whitten (2009:188) Story Face is an adaptation of story mapping, which also uses a visual framework for understanding, identifying and remembering elements in narrative text.

Recently the teachers are also challenged by the government to use the 2013 curriculum. According to Majid \& Rochman (2014:1), "the 2013 curriculum is competence-based process to boost the learning process and authentic assessment to attain attitudes, knowledge, and skills". The implementation of the 2013 curriculum is familiar with the words scientific approach. The application of this approach makes the students to learning model possibly to create a thought skill of science .According to (Dyer, 2011) in (Ridwan, 2015:53), "scientific approach is learning that has the components, they are components is, Observing, Questioning, Exploring, Associating, and Networking/Communicating".

Based on writer's experience in doing PPLT in SMK Swasta Dwiwarna Medan, English teacher in SMK Swasta Dwiwarna understands that students need more practice in reading English. By observing include the interview between the researcher and teacher, it found that story face is effective way to help students to understand the text but only some of students understand with teacher instruction. After doing preliminary research, it was found that some students face many difficulties in comprehending narrative text although the teacher has used story face.

\section{Review of Literature}

\section{Language Skill}

Language is essentially a skill. Skill related to different aspects of using language: such as listening, reading, writing and speaking. Skills are our ability to do these things. They are usually divided into two types namely: receptive 
and productive skill. Receptive skills are those used in understanding; reading or listening. Meanwhile, productive skills involve producing language; speaking or writing.

\section{Reading}

Reading is process of getting meaning from printed word symbols. It means that reading is more than mechanics unessential part of the process.Mikulecky (2008:1) writes that reading is a conscious and unconscious thinking process. With reading we can get more information about something and increase our knowledge.Reading can be defined as perceiving a written text in order to understand its content (Richard et al, 2002:454). Nuttal (1982:74) says reading as the meaningful interpretation of printed or written verbal symbols. Based on the definition above, the researcher conclude that reading is the readers' activity in order getting information and comprehend from printed text using eyes and brain to understand what the writer thinks in his/her written. Reading is a process to understand information by reading the reader can enlarge their knowledge. In English language there are four basic skills, they are speaking, writing, reading and listening. But the most important skill is reading. Because reading as a measure of student success in learning process.

According to Rivers and temperly cited in Hedge (2000:195), the purpose of reading are:

1) To get information.

2) To respond to curiosity about the topic.

3) Follow instruction to perform a task.

4) For pleasure, amusement, and personal enjoyment

5) To keep in touch with friends and colleagues.

6) To know what is happening in the world and find out when and where thing are 


\section{Narrative Text}

A narrative text is an imaginative story to entertain people. The word "story" may be used as a synonym of "narrative". A narrative can also be told by a character within a larger narrative. Narrative text is a written or oral text which tells fictional or nonfictional event in the past (National Literacy Trust, 2013). There are many types of narrative. They can be imaginary, factual or a combination of both.

The purpose of narrative text (Saragih, 2010:149 and Gerot, 2001:204) is to amuse or to entertain the reader with a story. The rhetorical structure and textual elements of narrative text consist of: (1) orientation, (2) complication, (3) resolution.

\section{Story Face as a Strategy in Teaching Reading}

Story Face is by giving a picture to make the students interest reading process. Staal in Klingner, J.K., Vaught, S., \& Boardman (2007:98) states that Story Face is an adaptation of story mapping that provides a visual frame work for understanding, identifying, and remembering elements in narrative text. The story face constructed by making the eyes, eyelashes, nose, mouth.

It is supported by Whitten et al (2009:188) Story Face is an adaptation of story mapping, which also uses a visual framework for understanding, identifying and remembering elements in narrative text. In this theory, he explains that Story Face used the frame work to make students understand about a text. Before the students reads a text the students should be identifying and remember about element of narrative text, so that the students reading the narrative text the students have background knowledge about text. Staal write that the Story Face is constructed by:

a. Making the eye: two circles representing the setting and main character.

b. Eyelashes: specific description and secondary characters.

c. Nose: problem.

d. Mouth: comprises a series of circles representing the man events that lead to the solution. 


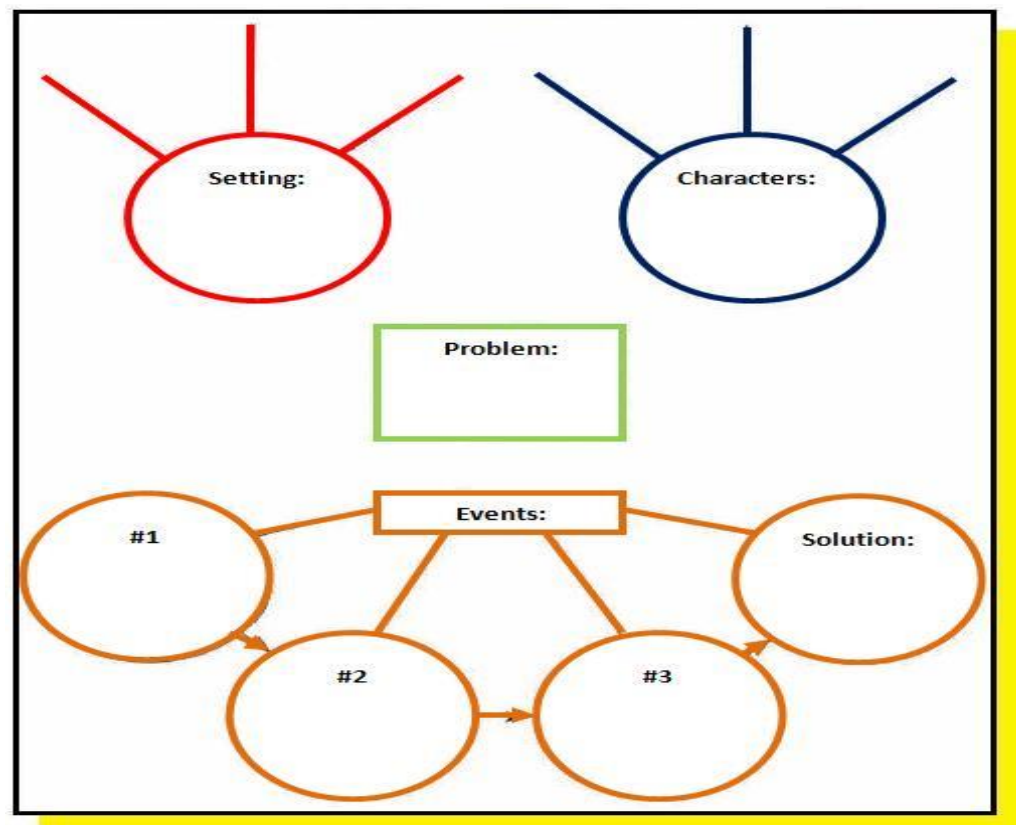

The Shape of Story Face

\section{Teaching Reading through Story Face}

In teaching reading, teacher uses strategy for interested students in reading subject. Teaching reading through story face is teaching reading with imagination and visualization to find mind of every component in each story. According to Randolp (2012), the main ways are:

1) Preview the story face with students prior to reading a narrative text.

2) Review the information that students should identify while reading.

3) Students read the text and fill out the story face.

4) Creating a story face

Students find their imagination through map and describe about the story their read. They will know setting, main character, problems, events, and a solution of the story. According to Staal that provides a visual framework for understanding, identifying, and remembering elements in narrative text.

Teaching reading through story face is teaching reading using strategy map with make a shape with the main component story and arrange to be one 
component looks like face. It helps students in teaching reading because students can visual or image the story. Teaching reading by using story face makes students understanding in reading material.

\section{Research Methodology}

The research was conducted to answer two questions mentioned in the problem formulation. They were process of teaching reading comprehension through story face of narrative text and students' problems in the process of learning reading comprehension through story face of narrative text. The data of the research was the students' worksheets of 20 students at grade tenth in SMK Swasta Dwiwarna Medan and the transcript of the students' interview. This study analyzed the data based on Miles, Huberman and Saldana's theory (2014).

\section{Research Findings and Discussion}

The Process of Teaching Reading Comprehension through Story Face

\section{First Meeting}

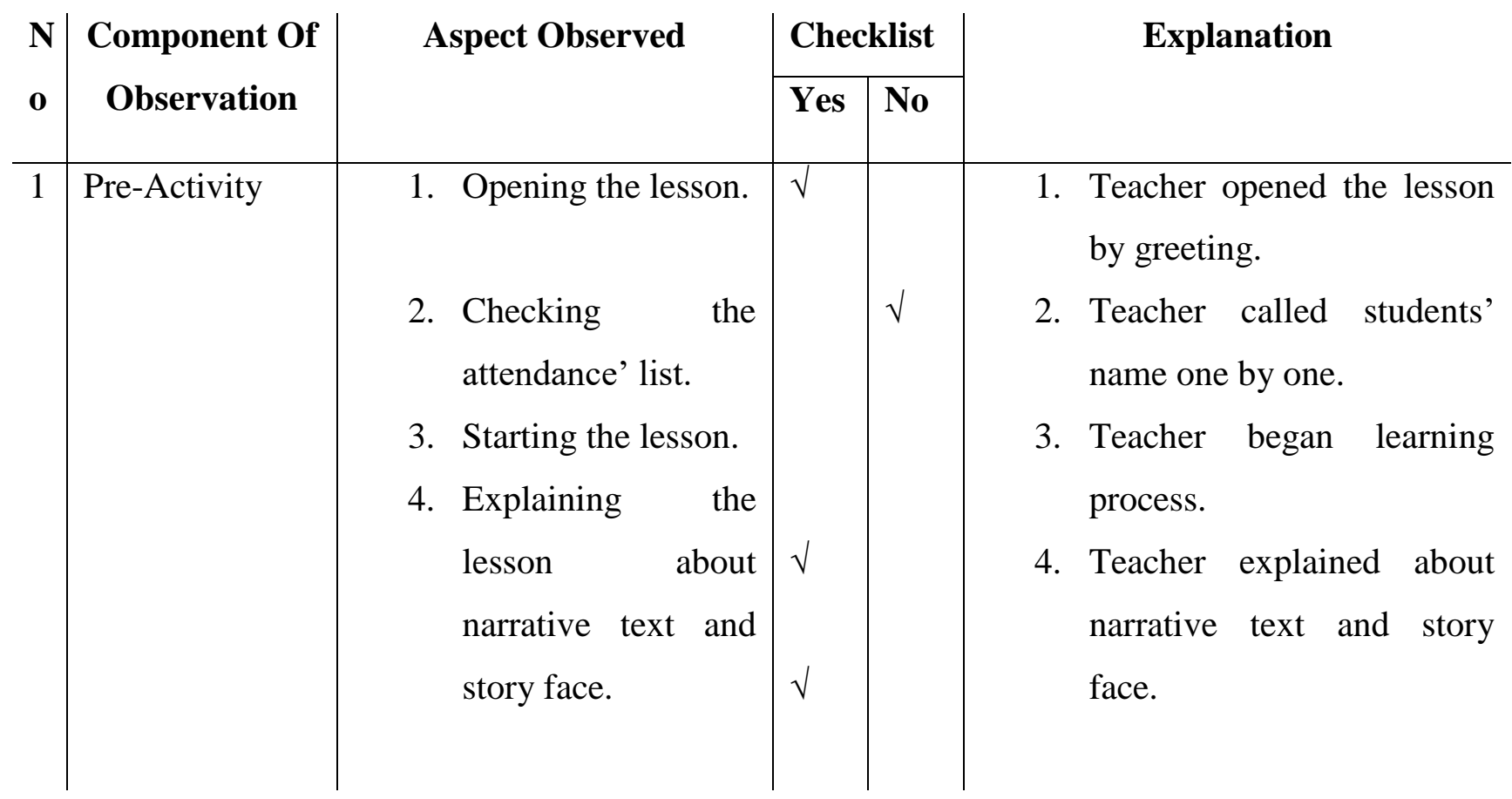




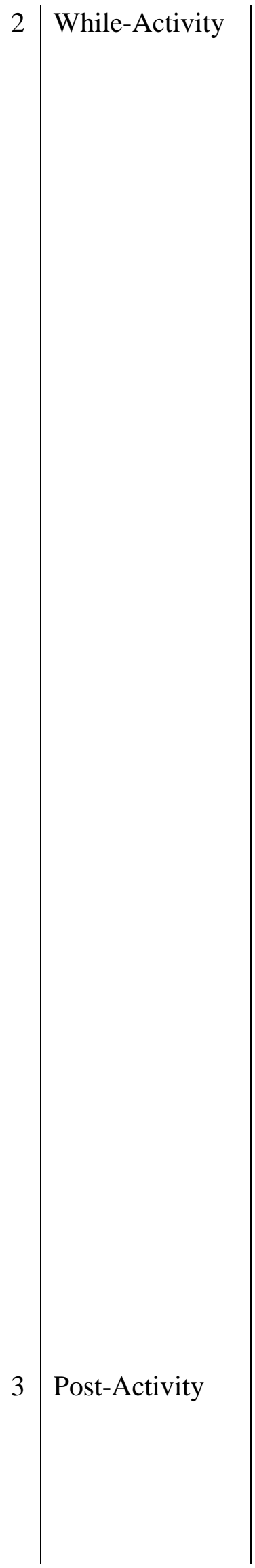

1. Reading the text $\sqrt{ }$ and explaining the generic structure of narrative text.

2. Applying Story Face in teaching reading.

3. Constructing story face.

1. Concluding the lesson.

2. Closing the lesson
1. Teacher read the text and explained the generic structure of narrative text.

2. The teacher explained story face in reading after shared the example of narrative text and the teacher starts to identify the text.

3. Teacher made the story face was constructed by making the eyes: two circles representing the setting and main character, eyelashes: specific descriptors and secondary characters, nose: problem, and mouth: comprises a series of circles representing the main events that lead to the solution and the teacher would fill out the story map as a visual for the students as both teacher and students important information for the story face.

1. Teacher concluded about the lesson today.

2. Teacher closed with salam. 
From the table above, it showed that in pre-activity, the class was opened by greeting that was responded by all students. Many of them responded loudly with enthusiasm, but some of them less responded. After that, teacher started the lesson and explained about narrative text and story face. Then in the Whileactivity, the teacher told the students that she would read the text and explain generic structure for the students understood how to apply story face in teaching reading. The teacher read the text until finished. After that, the teacher explained generic structure of narrative text. Then the teacher constructed story face. The teacher gave instruction to the students for identified together the text. Some of the students looked difficulty to identify text then the teacher help the students. After they identified the text, the teacher would fill out component of story face as a visual both of them. And they were read to identify important information for story face. And the last for Post-Activity, the teacher asks the students about generic structure of narrative text and applies story face. And then, the teacher concluded the lesson.

\section{Second Meeting}

\begin{tabular}{|c|c|c|c|c|c|}
\hline \multirow[t]{2}{*}{ No } & \multirow{2}{*}{$\begin{array}{c}\text { Component Of } \\
\text { Observation }\end{array}$} & Aspect Observed & \multicolumn{2}{|c|}{ Checklist } & \multirow[t]{2}{*}{ Explanation } \\
\hline & & & Yes & No & \\
\hline 1 & Pre-Activity & $\begin{array}{l}\text { 1. Opening the } \\
\text { lesson. } \\
\text { 2. Checking the } \\
\text { attendance' list } \\
\text { 3. Starting the } \\
\text { lesson. } \\
\text { 4. Explaining }\end{array}$ & $\sqrt{ }$ & $\sqrt{ }$ & $\begin{array}{l}\text { 1. Teacher opened the lesson by } \\
\text { greeting. } \\
\text { 2. Teacher did not call students' } \\
\text { name one by one } \\
\text { 3. Teacher began to teach } \\
\text { 4. Teacher explained how to use } \\
\text { story face. }\end{array}$ \\
\hline
\end{tabular}




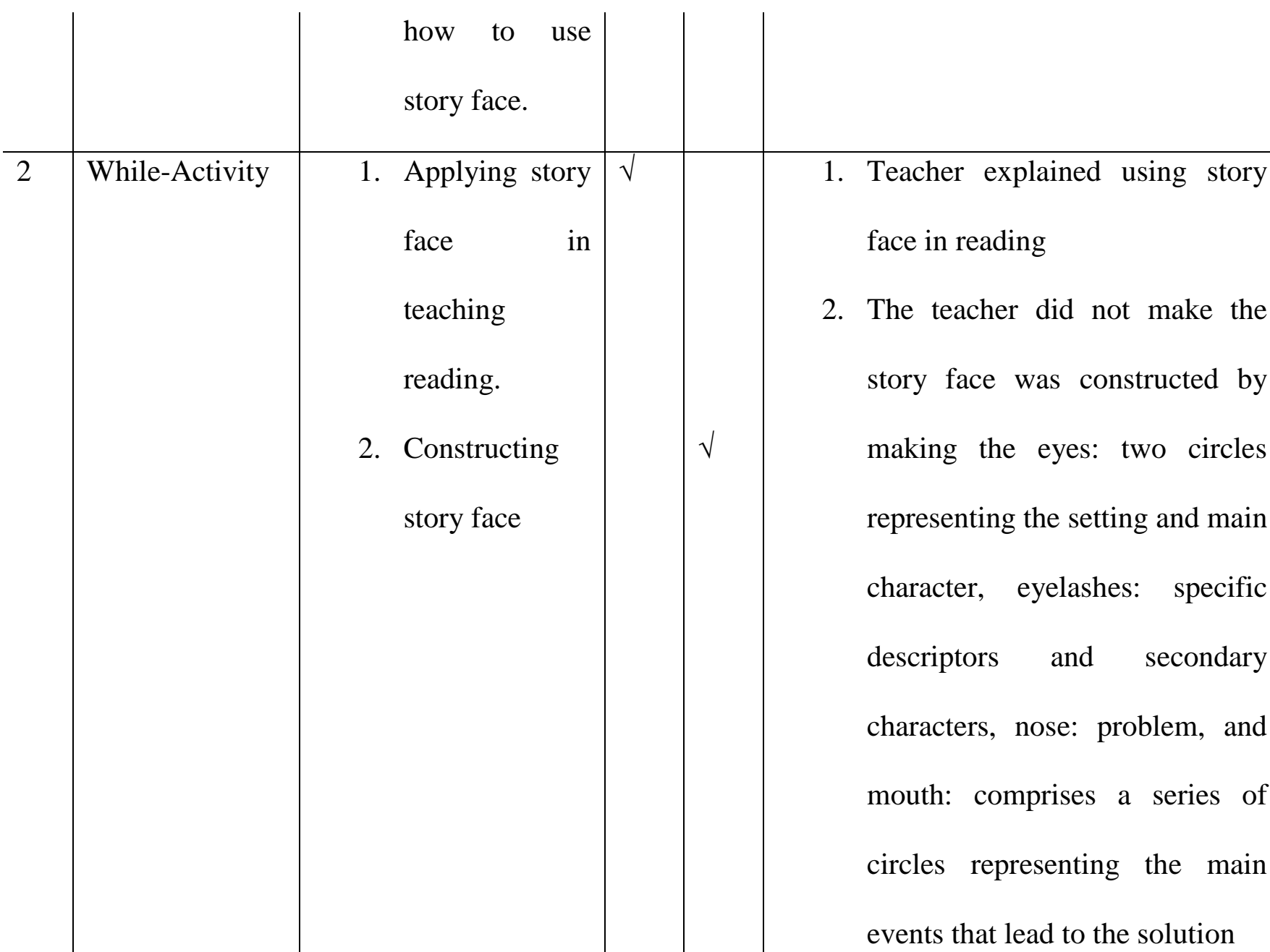

3. The teacher gave assignment to the students with another text

4. The students read the text and identify the generic structure of the text

5. The students filled out the story face 


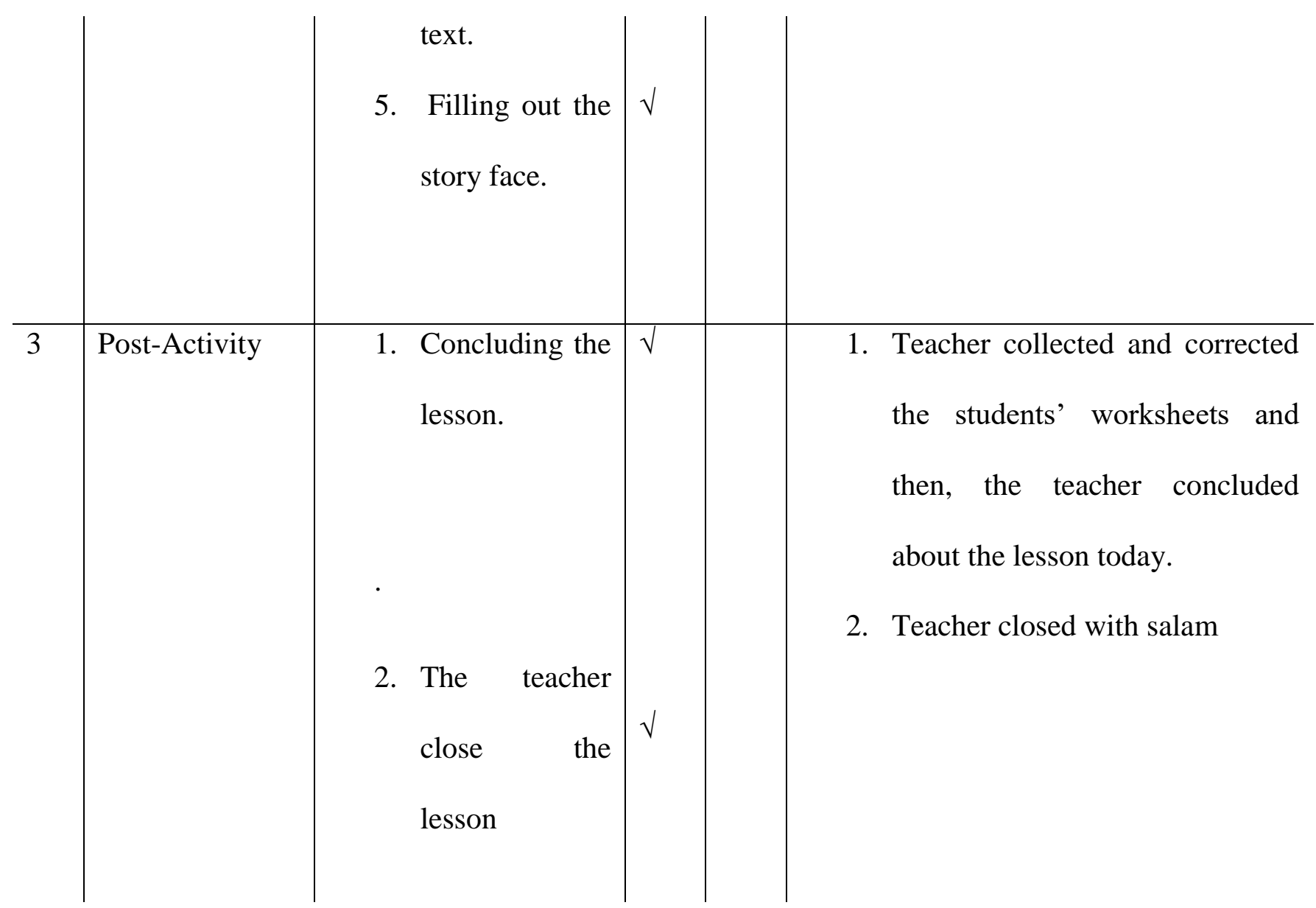

From the table above, it showed that in pre-activity, the class was opened by greeting that was responded by all students. Many of them responded loudly with enthusiasm, but some of them less responded. After that, teacher started the lesson and re-explained about story face and how to use it. Then, While-activity, the teacher gave assignment for the student and told the students that she would read the text and explain generic structure for the students understood how to apply story face in teaching reading as clear as possible. The teacher read the text until finished. After that, the teacher gave instruction to the students for identified the text like the example that was given by the teacher. Then the students constructed story face. After they identified the text, the students fill out component of story face as a visual both of them. And they were read to identify important information for story face. But some of the students looked difficulty to identify the text and then teacher help the students. 


\section{Students' Problems in the Process of Learning Reading Comprehension through Story Face of Narrative Text}

\begin{tabular}{l|l|l} 
No & Questions & Answer \\
\hline 1 & Does listen -read discuss helps & Yes, it helped me to comprehend the text \\
you to comprehend the text? & because the teacher present information \\
about the text before read the text and \\
conducted discussion after I read the text. \\
find
\end{tabular}




\begin{tabular}{|c|c|c|}
\hline & $\begin{array}{l}\text { Does your teacher is able to } \\
\text { make you being active during } \\
\text { learning reading comprehension } \\
\text { by using story face in the class? }\end{array}$ & $\begin{array}{l}\text { sometimes her joke was not funny and } \\
\text { made us bored. I think our teacher able } \\
\text { made us active during teaching learning } \\
\text { process. But most of the students were } \\
\text { passive during teaching learning process. }\end{array}$ \\
\hline 4 & $\begin{array}{l}\text { What are the difficulties that you } \\
\text { find in understanding the } \\
\text { meaning of a word or a sentence } \\
\text { in the text? }\end{array}$ & $\begin{array}{l}\text { Sometimes, I did not know the meaning } \\
\text { of a word and translated it by looking up } \\
\text { in dictionary or asking to the teacher, } \\
\text { moreover if that word was a word that I } \\
\text { had never seen before. Furthermore, } \\
\text { when I had known the meaning of a } \\
\text { word, I difficult translated the whole } \\
\text { sentence was weird although I had } \\
\text { checked the meaning of each word that } \\
\text { sentence in dictionary. }\end{array}$ \\
\hline 5 & $\begin{array}{l}\text { What are the problems that you } \\
\text { find in comprehending and } \\
\text { figuring out of the inference of } \\
\text { the text? }\end{array}$ & $\begin{array}{l}\text { I had problem to get main idea of the text } \\
\text { and to figure out inference of the text, I } \\
\text { did not understand the text well. One of } \\
\text { the reasons was because of less } \\
\text { vocabulary mastery and I did not practice } \\
\text { to read the text at home after I learned } \\
\text { English in the school. }\end{array}$ \\
\hline 0 & Does the text that was given by & No, because the teacher gave a long text \\
\hline
\end{tabular}




\begin{tabular}{|c|c|c|}
\hline & $\begin{array}{l}\text { the teacher can attract your } \\
\text { interest? }\end{array}$ & \\
\hline 7 & $\begin{array}{l}\text { Do you need a long time to read } \\
\text { and understand a text? }\end{array}$ & $\begin{array}{l}\text { Yes, I realize that I read text very slowly. } \\
\text { Sometimes, I translated words by looking } \\
\text { up in dictionary or asking to the teacher. I } \\
\text { am aware it waste of many times, but I } \\
\text { could not read the text quickly because I } \\
\text { did not know the meaning of a word or a } \\
\text { sentence. So, I need to translate it by } \\
\text { using dictionary or asking to the teacher. }\end{array}$ \\
\hline 8 & $\begin{array}{l}\text { What are the difficulties that you } \\
\text { find in memorizing the text that } \\
\text { you had read and discussed } \\
\text { before? }\end{array}$ & $\begin{array}{l}\text { I had problem to memorize the text we } \\
\text { had discussed before even to memorize } \\
\text { the meaning of words in the text, it might } \\
\text { happen because I rarely learn or practice } \\
\text { English outside the school after I learn } \\
\text { English in the school. Moreover, English } \\
\text { words are hardly used in my } \\
\text { environment, nobody used it, so it is so } \\
\text { hard to remember a new word/sentence. }\end{array}$ \\
\hline
\end{tabular}

The researcher found that students had some problems in learning reading comprehension through story face in SMK SWASTA DWIWARNA MEDAN. They were as follows: 
1) The students had no good vocabulary mastery. They still looked up in dictionary or asked to the teacher if they wanted to know the meaning of a word.

2) The students had problem to decode words and sentences.

3) Students had problem to get main idea of the text and to figure out the inference of the text. It was because of less vocabulary mastery and did not practice to read the text at home after they learn English in the school.

4) Students had habit of slow reading. They waste many of times for translating words and sentences in the text.

5) Students had problem in working memory. Working memory weakness might be consequence of poor language comprehension.

6) The students had problems with finding motivation and interest in learning reading. Then, they were being passive during learning process. Because, they did not confidence and they felt afraid to make a mistake in learning reading of narrative text.

\section{Conclusion}

Teaching reading by using story face could help the students in learning reading. The teaching reading comprehension by using story face was still less effective in grade tenth in SMK Swasta Dwiwarna Medan. There were many problems that could not manage well by teacher despite the teacher had followed the procedure well based on the Randolp (2012). There were still many weaknesses in several sides. But it did not give the big influence for teaching learning process, the process could be done properly. 
The problems faced by students in teaching reading comprehension by story face was students in SMK Swasta Dwiwarna have problems in reading comprehension trough story face, especially in the tenth grade in learning English have difficult to comprehending the text. The factors of the problems are: the students' less vocabulary, students confuse to understand the contain of the text because they don't know the meaning of the text, the students get difficulties to analyze a text to determine its generic structure because of slowly reading, the students get difficulties to catch the main idea of the text, bored with the situation during learning process

\section{Suggestion}

\section{For the English teacher}

a. Story face should be effectively to teach narrative

b. Teacher should be easier giving instructions to students

c. The teacher should be easier to open students imagination

\section{For other Researchers}

Teaching reading through story face makes the teacher easier to explain and make students enjoy and effective in learning reading to increase their reading.

\section{References}

Brown, H Douglas. 2000. Principles of Language Learning and Teaching 4th Edition. San Francisco: Addision Wesley Longman, Inc.

Brown, H. D. 2001. Teaching by Principles an Interactive Approach to Language pedagogy 2nd. San Francisco: Addision Wesley Longman, Inc.

Brown, H. D. 2004. Language Assessment and Principles and Classroom Practice. San Francisco: Addision Wesley Longman, Inc.

Brown, H.D. 2000. The principle of language learning and teaching. New jersey: Prenticehall. 
Carrel, L Patricia., Devine Joane., Eskey E David. 1988. Introduction: Interactive Approaches to Second Language Reading. New York: Cambridge University Press.

Carter, Ronald. 2005. Working with Text. London : Rouldge

Facilitator guide. 2005. Teaching Reading to adult English Language Learners. U.S : U.S Department of Education

Grabe, Wiliam. 2009. Reading in a Second Language Moving from Theory to Practice. Americas : Cambridge University Press.

Harmer and Jeremy. 1991. The practice of English language teaching. Singapore : Longman Group UK limited.

Harris, Karen. 2007. Teaching Reading Comprehension to students with Learning Difficulties. New York : Guildford Press.

John, W. 2012. Educational Research. United States : Pearson Education

Juliansyah, T. 2016. Teaching and Learning Reading through Story Face of the Eleventh Grade the First Semester at SMA Al-Azhar 3 Bandar Lampung in 2016/2017 Academic Year. Lampung : IAIN Raden Intan Lampung

Kemdikbud. 2013. Modul Pelatihan Implementasi Kurikulum 2013. Jakarta: Kebudayaan.

Kemdikbud. 2013a. Peraturan Menteri Pendidikan dan Kebudayaan Nomor 81 a tahun 2013 tentang Implementasi Kurikulum 2013. Jakarta: Kemdikbud

Kennedy, Eddie C. 1981. Method in Teaching Development Reading. Illinos: F.E. Peacock Publisher. Inc.

Klingner, J. K. 2007. Teaching Reading Comprehension to Students with Learning Difficuties. New York: The Guildford Press

Lundberg. 2004. Teaching Students with Reading Difficulties and Disabilities A Guide for Educators. America : Saskatchewan Learning.

Pardiyono. 2006. Pasti Bisa Teaching Genre-Based Writing. Yogyakarta: CV. Andi offset

Randolp, W. 2012. Common core teaching and learning strategies. Chicago: Illinois State Board of education. 
Staal, L. 2016. The story face: An adaption of story mapping that incorporate visualization and discovery learning to enhance reading and writing. Reading Teacher 54, 1, 26-31 